\title{
How people bereaved by suicide perceive newspaper reporting: qualitative study ${ }^{\dagger}$
}

\author{
Alison Chapple, Sue Ziebland, Sue Simkin and Keith Hawton
}

\section{Background}

People bereaved by suicide are often reported to be distressed by media reporting. Current media guidelines for reporting suicide focus especially on prevention of copycat behaviour.

\section{Aims \\ To explore bereaved individuals' experiences of media reporting after suicide and to examine their priorities in relation to media guidelines.}

\section{Method}

In-depth interviews with 40 people bereaved by suicide, with qualitative analysis. Review of four guidelines.

\section{Results}

There is a difference of emphasis between guidance for the press that aims to prevent copycat suicides (especially avoidance of details such as method used) and the perspectives of bereaved people (who prioritise sympathetic and accurate reporting, sometimes including details of the death and images of the person who died). We found that bereaved relatives were sometimes keen to talk to the press. Those who were upset by the press focused on careless reporting, misquoting and speculation that gave an inaccurate impression of the death.

\section{Conclusions}

The Leveson Inquiry has drawn attention to the damage that can be caused by irresponsible journalism. Guidelines written to prevent 'copycat' suicides are important, but so are the needs of bereaved relatives. Because accuracy matters greatly to the bereaved, families should be able to work with an intermediary such as a police press officer to prepare a statement for the press to minimise the risk of misrepresentation

\section{Declaration of interest}

None.
Lord Justice Brian Leveson's inquiry into the culture, practice and ethics of the press in the UK has recently heard that when the media get reporting wrong, the impact can be devastating and cause real harm to individuals and society. ${ }^{1}$ Bereaved and grieving families and friends may be particularly vulnerable to harm from press reports, especially when the death involves suicide. ${ }^{2}$ With notable exceptions ${ }^{2-4}$ few researchers have used in-depth, qualitative methods to explore how people bereaved by suicide perceive newspaper reporting. Wertheimer ${ }^{4}$ interviewed 50 people bereaved by suicide. Many said they had been distressed by media reports. The role of the media has also been raised in autobiographies ${ }^{5}$ and discussed more generally by sociologists. ${ }^{6}$ Several ways of improving reporting and portrayal of suicide have been suggested, ${ }^{7,8}$ including, for example, that researchers, clinicians, policy-makers and editors should work together to improve journalists' training. Journalists interviewed in a recent New Zealand study suggested that by reporting suicides they were promoting the public good as 'protectors and educators of the public.'

Much of the recent research concerning suicide and the media has focused on the relationship between media reports and imitative suicidal behaviour. ${ }^{10}$ In the New Zealand study quoted above journalists were sceptical of the imitative effects of suicide coverage, arguing that to exclude suicide from the news was the true danger. However, systematic reviews of the literature have concluded that suicide rates may rise after media reports of suicide, ${ }^{8}$ especially if the dead person was a celebrity, ${ }^{11}$ if the report glamorises the suicide, if reporting is prominent or if the method of suicide is discussed in detail. ${ }^{12,13}$ These findings have, appropriately enough, influenced guidelines for journalists ${ }^{14-16}$ and the UK Press Complaints Commission has produced a code of practice for journalists. ${ }^{17} \mathrm{~A}$ comparison of the issues the

'See editorial, pp. 168-169, this issue. guidelines and code of practice cover is provided in Table 1. However, the recommendations in these guidelines may not always match the needs of those who have been bereaved by suicide. Some guidelines acknowledge that the bereaved may be vulnerable themselves, and that they should be treated with respect. Journalists sometimes say that the bereaved want to talk about the death, but so far the evidence for this has been purely anecdotal. The aim of this study was to use qualitative analysis of narrative interviews to explore the experiences and needs of a diverse sample of individuals bereaved by suicide in relation to newspaper reporting of the deaths, and to consider these in the light of current guidelines for journalists.

\section{Method}

\section{Participants}

We invited people to take part in a study of experiences of bereavement from suicide. The study had national research ethics committee approval from Berkshire Research Ethics Committee (09/H0505/66). Potential participants were recruited through support groups, websites, general practitioners, a coroner's officer, our advisory panel, a newspaper article, the Safer Custody Group, a local radio programme, a conference and through snowball sampling. Those who expressed an interest received an information sheet, introductory letter, reply slip and envelope. All participants gave informed consent before taking part and consented to publication of their interview data.

We aimed for a diverse sample of men and women from different parts of England, Wales and Scotland, and from different social backgrounds and ethnic groups, who had lost a child, parent, sibling, cousin or friend. To maximise diversity we included some who had been bereaved recently (one woman lost her husband through suicide only 3 months before the interview) 
Table 1 The main issues mentioned in selected guidelines for reporting suicide, and in the Code of Practice ratified by the UK Press Complaints Commission 2011 (relevant to suicide)

\begin{tabular}{|c|c|c|c|c|}
\hline & $\begin{array}{l}\text { Samaritans, } \\
\text { UK }\end{array}$ & $\begin{array}{l}\text { AAS, AFSP and } \\
\text { APPC, USA }\end{array}$ & WHO & $\begin{array}{l}\text { UK Press Complaints } \\
\text { Commission }\end{array}$ \\
\hline Avoid explicit details in reports about method used & $\checkmark$ & 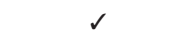 & $\checkmark$ & $\checkmark$ \\
\hline Phraseology important e.g.: avoid phrase 'committed suicide' or 'successful suicide' & $\checkmark$ & $\checkmark$ & $\checkmark$ & \\
\hline Avoid labelling places as suicide 'hotspots'- be cautious in reporting location & $\checkmark$ & $\checkmark$ & $\checkmark$ & \\
\hline Avoid simplistic explanations for suicide - there are usually multiple causes & $\checkmark$ & $\checkmark$ & $\checkmark$ & \\
\hline Avoid brushing over grim realities e.g. mention liver failure after an overdose & $\checkmark$ & & & \\
\hline Don't emphasise 'positive' results of a suicide e.g. reconciliation of separated parents & $\checkmark$ & & & \\
\hline Avoid disclosing the contents of any suicide note & $\checkmark$ & $\checkmark$ & $\checkmark$ & \\
\hline Encourage public understanding of the complexity of suicide & $\checkmark$ & & & \\
\hline Educate the public - expose common myths & $\checkmark$ & $\checkmark$ & $\checkmark$ & \\
\hline Include details of further sources of information, treatment and advice & $\checkmark$ & $\checkmark$ & $\checkmark$ & \\
\hline Avoid the use of dramatic photographs & 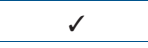 & $\checkmark$ & & \\
\hline Pictures of the person who has died should not be used & & & $\checkmark$ & \\
\hline Take particular care when reporting celebrity suicides - role models & $\checkmark$ & & $\checkmark$ & \\
\hline Avoid big sensational headlines and avoid prominent placement of photos & $\checkmark$ & $\checkmark$ & $\checkmark$ & \\
\hline Don't report suicide as you might report a crime - report it as a public health issue & & $\checkmark$ & & \\
\hline Do not publish inaccurate information - distinguish between conjecture and fact & & & & $\checkmark$ \\
\hline $\begin{array}{l}\text { Issues of accuracy are important to the bereaved who may want to review } \\
\text { the material before publication }\end{array}$ & 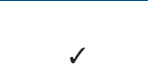 & & & \\
\hline Seek reliable sources when looking for background information or statistics & & $\checkmark$ & $\checkmark$ & \\
\hline Note that journalists are vulnerable and may be affected by reports of suicide & $\checkmark$ & & $\checkmark$ & \\
\hline Show consideration to the bereaved - respect privacy & 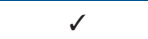 & & 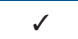 & $\checkmark$ \\
\hline
\end{tabular}

whereas others had been bereaved for some years (Table 2 provides details of the sample).

\section{Interviews}

In total, 40 people were interviewed (by A.C., a medical sociologist) in 2007 and 2008. Having signed a consent form people were asked to talk about their experiences. People talked about a wide range of issues, including the inquest, the funeral, support and the media. After this narrative part of the interview, an interview guide was used to explore relevant issues. If people had not talked about the media, they were asked about media involvement. The interviews lasted between 2 and $6 \mathrm{~h}$, and were audiotaped and fully transcribed for analysis.

\section{Analysis}

A qualitative interpretive approach was taken, combining thematic analysis with constant comparison. ${ }^{18}$ We used NUD ${ }^{\star}$ IST, QSR N6 (a qualitative data-indexing package) for Windows to facilitate the analysis (Qsr International, Doncaster, Australia, www. qsrinternational.com). Authors (A.C., S.Z.) read the relevant QSR N6 reports, discussed coding and interpretation of results, and used relevant literature to develop interpretation. These authors also examined the language that was used during the interviews. We use pseudonyms in reporting the results. Extracts and further analyses from the interviews, and more on our methods, can be found on www.healthtalkonline.org (formerly www.dipex.org), a resource based on qualitative studies of people's experiences of health and illness.

\section{Reviewing the guidelines}

We obtained copies of four sets of guidelines that are frequently cited in the literature. The Samaritans' guidelines ${ }^{14}$ are the main one used in the UK; those produced by the American Association of Suicidology, American Foundation for Suicide Prevention and the Annenberg Public Policy Center, ${ }^{15}$ and by the World Health Organization (WHO), ${ }^{16}$ are the main ones referred to internationally. The UK Press Complaints Commission refers to reporting of suicide in its Editors' Code of Practice. ${ }^{17}$ Our summary table (Table 1) compares the main issues highlighted in each as important for journalists to consider when reporting suicide.

\section{Results}

There is considerable correspondence between public health perspectives, drawing on suicide prevention research, and the components of the guidelines ${ }^{12,19}$ (Table 1). An important issue that all four include is 'avoid detail about the method used to carry out the suicide'. Three out of four (UK Samaritans, WHO and guidelines from the USA) highlight the importance of terminology (i.e. avoiding 'committed suicide' or 'a successful suicide'), avoiding simple explanations for the death, dramatic reporting and details about location, providing public education about resources, and recommend that the content of suicide notes should not be disclosed; the UK Samaritans, WHO and UK code of practice note that individuals should not be harassed. One guideline (WHO) suggests that the report should avoid using a photo of the person who died. The guidelines from the USA and the WHO suggest that reporters should use reliable sources when seeking background information about suicide and that they should interpret statistics carefully. The UK code of practice adds that reports must distinguish between comment, conjecture and fact, and that 'the Press must take care not to publish inaccurate, misleading or distorted information., ${ }^{17}$ The Samaritans guidelines are alone in also acknowledging that accuracy is particularly important to bereaved individuals, who are often upset if the 
Table 2 Characteristics of the 40 bereaved study participants Group that talked $n$ about the media, $n$

\begin{tabular}{|cr}
\hline Age at interview, years & \\
$27-40$ & 7 \\
$41-50$ & 9 \\
$51-60$ & 17 \\
$61-70$ & 7 \\
\hline Gender & \\
Men & 12 \\
Women & 28 \\
\hline
\end{tabular}

Occupation (some retired)

Professional

Other non-manual

Unskilled manual

Other e.g: housewife/student

Ethnic group

White British

White Australian

Indian

African-Caribbean

3

4

4

8

13

$27 \quad 12$

8

1

4

1

Relationship with deceased

Child (who lost a parent)

Brother or sister

Partner, husband or wife

Parent (who lost a child) Friend

\begin{tabular}{rr}
36 & 18 \\
1 & 1 \\
2 & 1 \\
1 & 1 \\
\hline
\end{tabular}

How people were bereaved

Hanging

Jumping

Car or motorbike or car fumes

Overdose

Car crash

Suffocation

Shooting

Railway

Drowning

Help from Dignitas

Burning

\begin{tabular}{rr}
6 & 2 \\
4 & 2 \\
10 & 5 \\
18 & 10 \\
2 & 2 \\
\hline
\end{tabular}

8

3

4

1

1

1

1

2

$-$

report contains inaccuracies. These guidelines point out that as accuracy in the details of the event is often of such importance to bereaved families it might be helpful for them to have the opportunity to check the copy before publication.

\section{Findings from the interviews}

Just under half of our interview sample said little or nothing about the media. Four had been young when the suicide took place and did not remember media reports. Some said that to their knowledge the death had not been reported, or that there had only been a short factual article. However, the other participants spoke at length about how they had engaged with the media and what was important to them about media involvement after the death.

\section{Managing the media}

Several people told us how they had actively engaged with the media. After her daughter's death Fiona wrote articles in local and national newspapers to raise awareness of bipolar disorder and its effect on family life. She was grateful to the journalists writing for a broadsheet, who she felt had done it 'beautifully'.

Fiona: I began to write [for the local paper] and once I'd started I couldn't stop, and I thought this is my opportunity to write a tribute to her [my daughter], and also to explain about manic depression, because so few people know [ . . . ] So there was Naomi on the front of the paper. And they did it beautifully. I was so grateful to them. It was very important to me. I felt now I would never have to explain again [ . . . ]. I got a letter from a professor of psychiatry who said it should be obliged reading for all

students of psychiatry because it explained the effect of manic depression on a family.

Interviewer: What about the press? In general have the press talked about it in other ways, and has it been what you wanted?

Fiona: Yes, they have. The local paper did a big thing when the book was coming out and had an interview with me. [ . . . ] It was good.

When Joanna's husband died she felt that the interview that she had done with a broadsheet newspaper had been cathartic for her as well as allowing her a platform to talk about mental illness. Both Joanna and Fiona mentioned that the articles meant that they did not have to keep re-telling what had happened. We have found that people bereaved by suicide use email and postings on social networking websites for a similar purpose. ${ }^{20}$

Mavis wanted to draw attention to how her daughter was treated in prison before she died. She prepared a statement with her solicitor and faxed it to an organisation called INQUEST (a charity that advises people whose relatives have died in custody), which wrote an article including her statement. She said that it was 'beautifully written for the cause'.

\section{Cooperating with the press}

Some people told us that the police had liaised with the press on their behalf. When Leila's partner died on the railway tracks it was reported in the local paper. A police press officer took a statement from Leila and her family:

So that they [the journalists] had something to go on so they would leave us alone to grieve and bury our man ... Until they've got the information they don't care about the people that are involved and the family, what they're going through. They just want their pound of flesh ... The police press man went off and typed it all up and brought it back for us to read and see that we were happy, and then he released our words effectively brushed up into posh speak, and a photo.

Simon's sister died by jumping in front of a train. He was concerned that the local paper might accompany the article about his sister with a picture of a 'cold train' as they had when someone else had died this way. Through the police family liaison officer he passed a photograph of his sister to the local editor, who used it for the article.

The local paper published a photograph. They had a story because there had been a tragedy on the railway lines locally, and there was a picture of the train, but fortunately before it [the account of his sister's death] was published we gave them a photograph of my sister [ ... ], and the police liaison officer, the lady, the local police photograph of my sister [... . and the police liaison officer, the lady, the local police
lady, she circulated the photograph so there wasn't just a picture of a cold train in the paper.

Alisa's response to the press was ambivalent. At first she hoped that newspaper coverage might help to find her friend, who was missing for a month before the body was found. Her only 'negative experience' was with the reporter who was at the coroner's court who 'just wouldn't leave me alone' although she made it clear that she didn't want to talk to the media. Alisa reflected during her interview that maybe it would have been better if she had been able to talk to the reporter because she might have been able to prevent the 'sensationalised' reporting.

And actually I think in retrospect it would've been better just to say something [um] because they did an inside page and made a great big issue of it with ... you know with massive letters, you know big lettering that you'd normally put on the front page. And in fact one or two of my friends wrote to the paper and complained that it had been sensationalised. But I do think in part it was you know it was ... it had ... if I had been more cooperative ... but I actually felt like that it wasn't that I didn't want to . . it was that I couldn't cope with it.

\section{Reasons for dissatisfaction with the Press}

Accounts from people who were unhappy about the behaviour of particular journalists included similar language to describe their objections. They reported being 'hounded' or 'door-stepped' by journalists they described as 'insensitive', 'unsympathetic', 'intrusive' or accused of 'snooping'. Recalling what happened after her husband died Melissa said: 
I really hated the fact that our tragedy would make up column inches. I felt that was a huge intrusion into our grief. And if he had died of cancer nobody would be reporting about his death. Although I have to say that the piece they wrote was very sympathetic.

Those who had encountered different journalists often distinguished between those who were empathic, careful and respectful and those they described as overly focused on getting the 'story', apparently disregarding the feelings of the bereaved. Mavis said some of the journalists she met had no respect for the dead. She continued to talk about her dead daughter as a person with social identity with whom she had a 'continuing bond' and strongly wanted to protect her dignity in death. She was understandably upset when a journalist suggested that a news report could do no harm:

Mavis: So that part of her [my daughter], whether it's her photograph or her name or whatever, they're not put out for people to pick over.

Interviewer: No.

Mavis: And that's her [my daughter's] right and privilege. [But] one reporter said to me 'Well, what harm can she come to, she's dead now?' and I said 'If that's what you believe I have nothing else to say'. I mean, that sort of takes your breath away.

\section{The central importance of accuracy}

People also explained why the way that the death was reported had upset them. These accounts invariably focused on careless reporting, speculation, guesswork and sensationalism. The central issue in their dissatisfaction with press reports was their accuracy. Lavinia was upset that one newspaper 'put some things in that were just, we felt, not true and quite insensitive'. She felt that the journalists had just guessed the details.

Mary, whose husband died, also complained about careless reporting and misquoting.

They were very casual in their reporting, [um] very careless. They didn't report things accurately. Even after the inquest they asked for a quote and I gave them a quote and they just changed it to suit themselves, so why ask for a quote if you're not going to use it. It's either a quote or a statement.

If there was no obvious explanation for the suicide, people did not want reporters or anyone else to speculate. Malcolm objected when a journalist speculated that his friend had taken his life because he was upset about the impact of HIV on the gay community. Karen was distressed by an article in the press that suggested that her two daughters' suicides were due to a 'suicide gene'. Karen who had two other children feared that this speculation about a 'suicide gene' might affect them and give them a reason for taking their lives too. She accused one freelance journalist of 'hounding' her and playing on her vulnerability, and others of writing a 'lot of fiction':

One of the newspapers wrote this article after Julia died about the suicide gene, that because their father had committed . . . it was a tabloid, and wrote about it as if it . . . it was being said, did my girls have the suicide gene. And I never ever have said that. And I don't believe in a suicide gene totally. And I thought that was so, so wrong of the newspapers to write this. No proof has ever been established that there is a suicide gene. I do not believe it. I just believe it was tragic events, just the circumstances.

As Wertheimer ${ }^{4}$ found in her research, even minor inaccuracies in news reports can distress bereaved friends and relatives. Sally was upset that when reporters finally wrote an article about her daughter (after 'hounding' the family) they spelt her name wrong. Rachana was upset because journalists reported that her brother was a business executive, when he was a shop owner. Melissa was annoyed that they got her husband's age wrong, even though the article was 'sympathetic'. Even when journalists take care to be accurate the newspaper headlines can give an inaccurate impression of what has happened. Joanna had wanted to talk to the press (although she felt that the article heading was misleading), but she recognised, 'That is the risk you take though, and I knew that before I went ahead, and on balance it was worth it'.

\section{Discussion}

Bereaved people in this study were worried about invasion of privacy, and clearly did not wish to be 'hounded' by reporters, but their main concern was that newspaper reports of the death should be accurate. Although WHO and American guidelines suggest that reporters must take care to publish accurate statistics and background information about suicide, of the four sets of guidelines in Table 1 only the UK Code of Practice highlights the need to distinguish between conjecture and fact and only the Samaritans mention that accuracy in the details is of particular importance to relatives. Perhaps the need for accuracy, an issue of particular concern to the Leveson Inquiry in the UK, is taken for granted by most of the world's press. However, a recent Hong Kong study in which the accuracy of local news reports was examined showed mass media demonstrated poor accuracy in reporting suicide risk factors. ${ }^{21} \mathrm{~A}$ comparison between the analysis of our interviews and the issues covered in the guidelines suggests a tension, and a difference of emphasis, between guidance for the press based on strategies to prevent copycat suicides (especially avoidance of certain details) and the perspectives of bereaved people (who feel they have a right to expect sympathetic and accurate reporting). There is a tension between a guideline that suggests that certain information should be withheld/not disclosed and a perspective that favours (in reports of an individual case) an accurate account, which may include such information (such as an image of the person who died).

Reporters do not have an easy task. They are often under pressure to produce a dramatic story as quickly as possible, with illustration from personal accounts, in which details may be simplified. $^{22}$ There are also mixed messages: WHO guidelines suggest that journalists should not use photographs of the person who died, yet families may offer photos. The WHO and other guidelines suggest that reporters should not use the phrase 'committed suicide' because it implies either criminality or a sin, yet reporters are likely to hear relatives using this phrase themselves (certainly, many of our respondents commonly used it). Reporters may want to reflect the language used by the person they have interviewed, and indeed face criticism from families if they do not. Journalists may be of help to the bereaved, especially if they remember that accuracy, even of apparently small details, is hugely important to family members and friends. However, perhaps journalists should explain to relatives that certain reporting might be irresponsible. It is not reasonable to expect people bereaved by suicide to know what sort of reporting may be harmful but it is reasonable to ask journalists to be mindful of the guidelines and the research that underpins them. Also, if reporters follow suggestions in the guidelines about providing details of sources of support (such as helplines and support groups) in their articles they can contribute positively to suicide prevention. Sources of help in the UK include Survivors of Bereavement by Suicide (www.uk-sobs.org.uk) and the booklet Help is at Hand. ${ }^{23}$

\section{Strengths and weaknesses}

A strength of this qualitative study is that we conducted in-depth interviews with a broad sample of people. By encouraging the participants to talk about what mattered to them we heard about events that might not have emerged in a questionnaire study. We attended not only to what respondents said but also to the language and phrases they used during the interviews. The study included people living in different areas so they had experience of many reporters working for a range of national and local newspapers. The sample was not intended to represent those 
bereaved by suicide numerically; rather, we sought to represent a broad range of experiences, as is appropriate to the aims of this qualitative study. However, we would have liked to have included more manual workers, and more people from Black and minority ethnic groups; had we done so additional perspectives might have emerged. These are necessarily partial accounts; other members of the family, or the person's social network, might have reported different views of any media coverage.

\section{Implications for health professionals}

In contributing to guidelines for reporters writing about suicide healthcare professionals should be aware that although preventing 'copycat' suicides is very important, the needs of bereaved relatives should be remembered. Clinicians supporting people bereaved by suicide should realise that if accuracy of reports is respected, people might not always find the press intrusive. Some have good reasons and a strong urge to communicate what has happened. Others might be guided to intermediaries, such as police family liaison officers, who can help them prepare a press statement.

\section{Future research and implications for journalists}

Research similar to that conducted in Australia, ${ }^{24}$ Hong Kong ${ }^{25}$ and the $\mathrm{USA}^{26}$ (with media content analysis) could assess how far reporters in other countries are complying with media guidelines. This could include evaluation of the impact of specific guidance on restricting reporting details of methods of suicide. ${ }^{17}$ It should examine the apparent sensitivity of reports to bereaved people's needs. The training of journalists should incorporate the need for accurate, sensitive and responsible reporting on suicide. ${ }^{27}$ It would also be useful to find out how journalists view these codes, and to include bereaved relatives' perspectives in training for journalists.

As we have shown, not all bereaved relatives have a negative view of the media and the reporting of suicide. However, many people feel uncomfortable in dealing with the media. Because accuracy is so valued it may be in the best interests of families to work with an intermediary such as a police press officer or family liaison staff to prepare a statement for the press, since this lessens the danger of misrepresentation. Such support may help grieving families to ensure that newspapers get accurate information, avoiding either misunderstandings or the feeling that they have been intruded upon.

Alison Chapple, PhD, Sue Ziebland, MSc, Department of Primary Health Care Sciences, Health Experiences Research Group, University of Oxford, Oxford; Sue Simkin, BA, Keith Hawton, DSC, FRCPsych, Centre for Suicide Research, University of Oxford Centre for Suicide Research, Department of Psychiatry, Warneford Hospital Oxford, UK

Correspondence: Alison Chapple, Department of Primary Health Care Sciences, Health Experiences Research Group, University of Oxford, 2nd floor, 23-38 Hythe Bridge Street, Oxford OX1 2ET, UK. Email: Alison.chapple@phc.ox.ac.uk

First received 4 May 2012, final revision 3 Sep 2012, accepted 26 Nov 2012

\section{Funding}

The Department of Health for England and Wales. S.Z. is funded by the NIHR National school for Primary Care Research. K.H. is a National Institute for Health Research Senior Investigator.

\section{Acknowledgements}

We thank the people who took part in the interviews, our advisory panel, and all those who helped us to recruit. We also thank John Lister and Andrew Hexheimer for their help with an earlier draft of this article.

\section{References}

1 Mooney H. More "responsible" science reporting is needed, Leveson inquiry hears. BMJ 2011; 343: d8051.

2 Harwood D, Hawton K, Hope T, Jacoby R. The grief experiences and needs of bereaved relatives and friends of older people dying through suicide: a descriptive and case-control study. J Affect Disord 2002; 72: 185-94.

3 Biddle L. Public hazards or private tragedies? An exploratory study of the effect of coroners' procedures on those bereaved by suicide. Soc Sci Med 2003; 56: 1033-45.

4 Wertheimer A. A Special Scar: The Experiences of People Bereaved by Suicide (2nd edn). Routledge, 2001.

5 Davies AM. Shades of Suicide: Open Verdict/Suicide Bereavement. March Hare UK, 2006.

6 Howarth G. Death and Dying: A Sociological Introduction. Polity Press, 2007.

7 Crane $C$, Hawton $\mathrm{K}$, Simkin S, Coulter P. Suicide and the media: pitfalls and prevention. Crisis 2005; 26: 42-7.

8 Pirkis J, Blood W. Suicide and the News and Information Media. Mind Frame Media, 2010 (www.mindframe-media.info).

9 Collings S, Kemp C. Death knocks, professional practice, and the public good: the media experience of suicide reporting in New Zealand. Soc Sci Med 2010; 71: $244-8$.

10 Blood RW, Pirkis J. Suicide and the media: part 3. Theoretical issues. Crisis 2001; 22: 163-9.

11 Niederkrotenthaler T, Till B, Kapusta N, Voracek M, Devic K, Sonneck G. Copycat effects after media reports on suicide: a population-based ecologic study. Soc Sci Med 2009; 69: 1085-90.

12 Hawton K, Williams K. Influences of the media on suicide. BMJ 2002; 325 : $1374-5$.

13 Lee D, Chan K, Lee S, Yip PSF. Burning charcoal: a novel and contagious method of suicide in Asia. Arch Gen Psychiatry 2002; 59: 293-4.

14 The Samaritans. Media Guidelines for Reporting Suicide and Self-Harm. The Samaritans, 2008 (www.samaritans.org/media_centre/media_ guidelines.aspx)

15 American Association of Suicidology, American Foundation for Suicide Prevention, Annenberg Public Policy Center, Canterbury Suicide Project University of Otago, Columbia University Department of Psychiatry, ConnectSafely.org, et al. Recommendations for Reporting on Suicide (Reportingonsuicide.org/Recommendations2012.pdf).

16 World Health Organization. Preventing Suicide: A Resource for Media Professionals. WHO Press, 2008.

17 Press Complaints Commission. Editors' Code of Practice. Press Complaints Commission, 2011 (www.pcc.org.uk/cop/practice.html).

18 Glaser B, Strauss A. The Discovery of Grounded Theory. Aldine Publishing, 1967.

19 Pirkis J, Blood W, Beautrais A, Burgess P, Skehan J. Media guidelines on the reporting of suicide. Crisis 2006; 27 : 82-7.

20 Chapple A, Ziebland S. How the internet is changing the experience of bereavement by suicide: a qualitative study in the UK. Health 2011: 15: $173-87$.

21 Cheng Q, Yip PSF. Suicide news reporting accuracy and stereotyping in Hong Kong. J. Affect Disord 2012; 141: 270-5.

22 Seale $C$. How the mass media report social statistics: a case study concerning research on end-of-life decisions. Soc Sci Med 2010; 71: 861-8.

23 Department of Health. Help is at Hand: A Resource For People Bereaved by Suicide and Other Sudden, Traumatic Death. Department of Health, 2010 (www.dh.gov.uk/en/Publicationsandstatistics/Publications/ PublicationsPolicyAndGuidance/DH_115629).

24 Pirkis J, Dare A, Blood RW, Rankin B, Williamson M, Burgess $P$, et al. Changes in media reporting of suicide in Australia between 2000/01 and 2006/07. Crisis 2009; 30: 25-33.

25 Au J, Yip P, Chan C, Law Y. Newspaper reporting of suicide cases in Hong Kong. Crisis 2004; 25: 161-8.

26 Tatum P, Canetto S, Slater M. Suicide coverage in US Newspapers following the publication of the media guidelines. Suicide Life Threat Behav 2010; 40: 524-34.

27 Skehan J, Sheridan Burns L, Hazell T. The Response Ability Project: integrating the reporting of suicide and mental illness into journalism. Journal Mass Commun Educ 2009; Summer: 192-204. 